\title{
A REDE DE COMERCIALIZAÇÃO AGRÍCOLA NO RIO DE JANEIRO: PROCESSOS, DIMENSÕES, TÉCNICAS E AGENTES
}

THE AGRICULTURAL MARKET IN RIO DE JANEIRO: PROCESSES, DIMENSIONS, TECHNIQUES AND AGENTS

\author{
Rogério Seabra ${ }^{1}$ \\ ${ }^{1}$ Instituto Brasileiro de Geografia e Estatística (IBGE), Rio de Janeiro, RJ, Brasil \\ Correspondência para: Rogério Seabra (rogerioseabra@gmail.com) \\ doi: 10.12957/geouerj.2017.32066 \\ Recebido em: 1 nov. 2017 | Aceito em: 12 dez. 2017
}

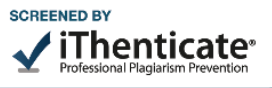

\section{RESUMO}

O mercado de gêneros agrícolas no Brasil, e consequentemente no Rio de Janeiro, foi estruturado a partir do crescimento da demanda urbana e das possibilidades produtivas da policultura de pequena escala, já que a estrutura fundiária concentrada e o monocultivo exportador ocupam tradicionalmente o campo brasileiro. Atualmente, a propriedade da terra continua sendo uma questão para produtores familiares da Região Serrana Fluminense contudo, os entraves e possibilidades relacionados ao processo de comercialização foram alterados. Os antigos atravessadores aparecem com uma nova roupagem mediados, agora, pelo diferencial logístico de complexos operadores logísticos. Tais transformações atuam reconfigurando formas de comercialização, isto é, a rede de distribuição de gêneros agrícolas, além de fomentar novas articulações e interações entre supermercados e o sistema CEASA-RJ.

Palavras-chave: comercialização agrícola; supermercados; sistema CEASA-RJ.

\section{ABSTRACT}

The agricultural market in Brazil, and consequently in Rio de Janeiro, was structured by the growth of urban demand and the possibilities of the small-scale police for familiar production. Nowadays, the land property continues to bean an issue for the family producers of the Serrana Fluminense region, however, the possibilities related to the commercialization process have changed. The old forms of commercialization appear with a new way mediated, now, by logistic operators. These transformations are reconfiguration forms of commercialization, as well as fostering new articulations and interactions between supermarkets and CEASA-RJ systems.

Keywords: agricultural marketing; supermarkets; CEASA-RJ system.

\section{INTRODUÇÃO}

O mercado de gêneros agrícolas no Brasil, e consequentemente no Rio de Janeiro, foi estruturado a partir do crescimento da demanda urbana e das possibilidades produtivas da policultura de pequena escala, já que a estrutura fundiária concentrada e o monocultivo exportador ocupam tradicionalmente o campo brasileiro.

Apesar do domínio da grande produção, Prado Jr. (2000), na década de 1960, já apresentava a existência da agricultura familiar, sobretudo a produção de hortigranjeiros para o autoconsumo e o 
abastecimento urbano. Também relacionava a potencialidade, desde que garantido o acesso à terra e a transformação das relações sociais de produção.

De fato, as falhas no sistema de abastecimento eram (e continuando sendo) mais complexas do que entraves pontuais no sistema de transporte, por distância elevada entre produção e consumo ou baixa produtividade agrícola, mas decorrentes da interação desses elementos com outros elementos da economia e da sociedade.

Como processo histórico, no entanto, Linhares (1979) explica as crises de abastecimento com base no domínio da grande produção exportadora e posição marginal da policultura para o abastecimento das cidades e da subsistência. Na verdade, segundo a autora, há momentos distintos no abastecimento, isto é, o enfraquecimento conjuntural da exportação representava uma rápida metamorfose no sistema produtivo e de abastecimento.

Nessa linha, Moreira (2011) relaciona a localização das áreas de policultura ao mecanismo de expansão da grande produção, com rebatimentos diretos no sistema de abastecimento. Conforme indica o autor,

\footnotetext{
A policultura acompanha a trajetória migrante desta (grande lavoura), em função da qual se distingue sob duas formas: a que nasce nas linhas de frente e a que nasce na retaguarda. Enquanto a policultura da linha de frente é dinâmica, a da retaguarda incorpora o quadro de decadência e abandono do espaço pela grande lavoura em sua marcha para adiante. Daí que a policultura da linha de frente seja igualmente de mercado e itinerante (MOREIRA, 2011, p. 71).
}

Entre as variações conjunturais no binômio produção e abastecimento, a mineração revela a estruturação de um sistema orientado ao mercado urbano que, após sua decadência, foi direcionado, em parte, para a atual cidade do Rio de Janeiro (LINHARES, 1979). As transformações conjunturais não eliminaram ou criaram o problema do abastecimento. Na prática, a sazonalidade e a imprevisibilidade são os estruturantes do sistema de abastecimento no Brasil e no Rio de Janeiro ao longo do século XIX e início do XX. 
No geral, como estabelecem Linhares (1979) e Gawryszewski (2002), o início do século XX foi marcado por muitos problemas de abastecimento e pela responsabilização dos canais de abastecimento pelos problemas de escassez de produtos no cotidiano urbano. No mesmo período, como indica Bicalho (1992), a expansão demográfica na área metropolitana reorganizou as relações e as localizações entre área de consumo e produção de gêneros agrícolas no espaço fluminense.

Retornando aos argumentos de Linhares (1979), a autora relaciona o crescimento da demanda por produtos na área urbana carioca e na crescente baixada fluminense ao surgimento de empresas de comercialização. Em outras palavras, a demanda gerada pelo crescimento demográfico e urbano empurrava a produção para áreas mais longínquas, exigindo, portanto, uma organização logística apropriada ao novo ritmo e à intensidade de comercialização (GALVÃo, 2009).

Segundo Linhares (1979),

\begin{abstract}
A organização da produção para o abastecimento exigiu a montagem de uma estrutura de transportes e de comercialização que escapava às possibilidades reduzidas do pequeno produtor. Este, quando situado na periferia de um centro consumidor em expansão, como foi o Rio de Janeiro, ou entregava seus produtos às empresas (de transporte) que se formavam e progrediam ou, então limitava-se a colocar seus reduzidos excedentes no mercado ambulante (p. 163).
\end{abstract}

A permanência do pequeno produtor integrado ao grande circuito de comercialização estava atrelada ao procedimento de inclusão da sua produção ao modelo controlado pelas empresas intermediárias da comercialização. À medida que aumentava a distância (física e de interação social) entre produtores e consumidores, os intermediários ganhavam força na gestão dos fluxos de gêneros agrícolas.

A manifestação da crise de abastecimento não representa apenas a falta de produto agrícola; há problemas na qualidade do produto e problemas de precificação. Lavinas e Nabuco (1992) detalham várias políticas públicas com o objetivo de contornar as revelações dos problemas de abastecimento no Estado do Rio de Janeiro.

Segundo as autoras, no início do século XX, as ações atuavam basicamente por meio de mecanismos de controle de preços dos produtos, ora viabilizando as importações, ora reduzindo os impostos para os 
produtos agrícolas. Na prática, as intervenções foram pontuais e não atuaram sobre problemas ao longo de toda a cadeia produtivo-logística.

Gawryszewski (2002) debate a crise no abastecimento carioca a partir das ações cotidianas da população para tentar reverter os problemas gerados pelo Estado, grande culpado pela situação caótica no sistema de abastecimento. O Estado como regulador, fiscalizador e formulador de políticas públicas torna-se alvo das demandas por alimentos da crescente população na área metropolitana.

As ações nas décadas de 1930-40 continuam buscando, com base em decretos e ações pontuais, resolver os problemas no abastecimento carioca. A principal conduta do governo ainda era equacionar o sistema a partir dos preços praticados, por exemplo, como indica Gawryszewski (2002):

Em 18 de novembro de 1938 foi decretada a Lei número 869 sobre Crimes contra a Economia Popular, que punia todos aqueles que destruíssem mercadorias, fraudassem pesos, contribuíssem para o aumento ou queda nos preços por meio de notícias falsas. Quem cometesse tal crime seria preso e julgado pelo Tribunal de Segurança Nacional (p. 30).

Sem dúvidas, há validade na ação pública de controle de preços ao consumidor, pois existe uma relação entre preço do produto, renda e capacidade de consumir produtos agrícolas. Contudo, reitera-se a incapacidade de transformações estruturais em práticas desse tipo por priorizar mecanismos pontuais para cadeias de abastecimento.

Os momentos de crise no abastecimento são derivados, em sua maioria, de fatores logísticos e socioeconômicos e, dificilmente, decorrem da incapacidade produtiva ou têm na distância o principal entrave. Ao longo do século XX, por conseguinte, "dentro da perspectiva do discurso e das leis" (GAWRYSZEWSKI, 2002, p. 35) as políticas públicas tentaram equalizar a oferta de produtos e controlar os preços dos produtos agrícolas. Contudo, ao abordar o problema pelo preço ou como uma consequência natural (baixa fertilidade, falta de chuvas, relevo etc.), não se pensou no problema de forma sistêmica. 
Guimarães (2009) reforça, com Prado Jr (2000), o papel do latifúndio e do monocultivo na consolidação do sistema de abastecimento nacional, ou seja, marginalizando a policultura e o mercado nacional em detrimento das exportações. De acordo com Guimarães (2009),

\begin{abstract}
As condições terrivelmente opressivas vigentes nos primeiros séculos, que esmagavam no nascedouro o despontar da classe dos pequenos cultivadores independentes, forçando-os a engrossar os contingentes de rendeiros empobrecidos, lavradores obrigados e agregados ou moradores dos engenhos e fazendas, contribuíram também para limitar a expansão da agricultura, para retardar ou impedir a diversificação dos cultivos e para atirar ou manter na ociosidade uma cada vez mais numerosa massa humana (p. 51).
\end{abstract}

Atualmente, diante de outro contexto histórico e de uma conjuntura política e econômica diferente, o acesso à propriedade da terra ainda é uma questão para os trabalhadores rurais no circuito Tere-Fri (Teresópolis - Nova Friburgo).

Um outro aspecto do abastecimento, como novamente elucida Gawryszewski (2002), na década de 1940, é que a legislação criou a Comissão Nacional de Preços. Dentre os vários objetivos, ressaltam-se aqueles associados ao controle inflacionário de preços agrícolas, mas, em contrapartida, não há uma preocupação com a renda do produtor familiar. Na verdade, a comissão buscou reduzir a população das favelas na então capital levando-as ao campo para aumentar a produção. A política foi um fracasso, pois o êxodo rural continuou e foi ampliado pela modernização na agricultura.

Mais um exemplo das tentativas pontuais e falhas das políticas públicas na primeira metade do século XX aparece na Comissão Central de Preços (GAWRYSZEWSKI, 2002) em 1946. O principal objetivo era o tabelamento de preços dos produtos agrícolas, estabelecendo um controle sobre os preços nas áreas urbanas. Entretanto, como afirma Gawryszewski (2002),

Os preços eram estabelecidos pela Comissão Central de Preços por regiões ou por cidades. Tal fato acarretou para a cidade do Rio de Janeiro problemas de ordem de abastecimento, pois seus preços eram tabelados por valores inferiores aos de várias cidades ou regiões, inclusive próximas, ocasionando desvios de mercadorias da cidade do Rio para estas regiões ou cidades (p. $53)$.

\title{
Problemas de abastecimento e a intervenção federal: o sistema de centrais de abastecimento
}


Na década de 1970, o Governo Federal, a partir do Decreto n. 70.502, de 11 de maio de 1972, cria o SINAC - Sistema Nacional de Centrais de Abastecimento - vinculado ao controle técnico, financeiro e administrativo da COBAL - Companhia Brasileira de Alimentos. Pelo decreto ficou estabelecido que, via SINAC, o sistema de abastecimento efetivaria troca de informações de comercialização, como, por exemplo, preços, padronização, classificação e embalagem dos produtos agrícolas, apresentando uma forma clara de regulação pública no sistema de distribuição.

O modelo da CEASA, como indica Cunha (2006), "foi desenvolvido em uma perspectiva sistêmica" (p. 38) justamente pela ação do SINAC, ou seja, o sistema federal

tinha como proposta inicial o estabelecimento de uma rede de informações técnicas entre as unidades atacadistas regionais para servir como ponto de referência aos negócios entre produtores, propiciando o melhor ponto de equilíbrio da oferta e dos preços (p. 38).

As metas e as ações materializadas pela instalação do sistema CEASA impuseram normas e regras padronizadas para a comercialização ao contrário dos sistemas paralelos oriundos da regulação (ou da falta dela) do mercado. Na prática, a centralidade exercida pelo CEASA não criou um sistema público exclusivo, tampouco eliminou atravessadores. No entanto, reorientou os fluxos de comercialização a partir da criação de uma unidade atacadista centralizadora da produção.

A relação entre a esfera pública e a privada fica evidente com a contribuição de Cunha (2006). Para ele, o fomento estatal

fez com que as Ceasa brasileiras cresceram sob o duplo estímulo da força coercitiva, associada a leis de proibição de comércio atacadista fora dos espaços delimitados dos entrepostos, com vantagens econômicas, incentivos e privilégios aos comerciantes atacadistas recém-instalados. Essa situação de duplo estímulo, com a criação de um empresariado regulado e ao mesmo tempo privilegiado, foi útil, mas, ao fim, limitador da expansão do modelo CEASA. Generalizou-se, nesse período, uma imagem de apropriação privada de benesses públicas dos agentes privados, como intermediários não funcionais ou como forças de cartel (p. 39).

A ação central do governo via SINAC e CEASA fomentou o fortalecimento de alguns intermediários e, de fato, o mercado atacadista público funcionava com empresas privadas operando nas centrais por concessão, permissão ou via remuneração, conforme indica o artigo $8^{0}$ do Decreto n. 70.502 . 
Entretanto, a política nacional de criação do CEASA considerou, pela primeira vez, em uma articulação sistêmica da comercialização agrícola, criando um representativo entreposto comercial, nó fundamental para produtores e varejistas.

O sistema SINAC e CEASA projetado e materializado na década de 1970 está relacionado aos grandes investimentos da Ditadura Civil-Militar brasileira e ao acesso ao crédito barato disponível no cenário internacional. A lei de criação do sistema federal faz parte do Primeiro Plano Nacional de Desenvolvimento ${ }^{1}$. Consequentemente, a crise financeira internacional, o endividamento nacional e a redução do Estado na década de 1980 também influenciaram o funcionamento do sistema CEASA.

O entreposto comercial, importante para produtos e comerciantes, representado pelo CEASA-RJ (2014), não eliminou os intermediários-atravessadores. Apesar de reorientar práticas e fluxos, não aproximou os produtores e consumidores. Na verdade, como defendeu o então presidente da COBAL, Vilela (1978), era inviável que

\footnotetext{
Ainda hoje postulamos por sistemas quiméricos de comercialização, que prescindam de quaisquer intermediários, como condição única para melhorar as relações de troca da agricultura com os demais setores da economia. Qualificando indiscriminadamente a todos de perniciosos e/ou desnecessários, em verdade damos uma demonstração cabal de desconhecimento do processo de comercialização que, em qualquer sistema econômico, deles não pode prescindir na realização de funções especializadas, dificilmente assumíveis pelo produtor rural enquanto tal (p. 3).
}

A posição do representante da COBAL destacava a eficiência e a necessidade do intermediário para a comercialização, reforçando o argumento anteriormente apresentado, ou seja, o sistema CEASA-RJ não eliminou os atravessadores; tampouco era seu objetivo eliminá-lo.

Ainda sobre esse período, em um encontro promovido pela CONAB, os dirigentes das centrais de abastecimento do país buscaram avaliar o papel dos mercados atacadistas após uma década de funcionamento. Entre os problemas levantados, o estudo (DECEN $\left.{ }^{2} / \mathrm{CONAB}, 1983\right)$ apontou as dificuldades técnicas do sistema CEASA brasileiro para sistemas de gestão e novas tecnologias,

\footnotetext{
${ }^{1}$ Lei n. 5727, de 4 de novembro de 1971.

${ }^{2}$ Departamento de Centrais de abastecimento da CONAB.
} 
entraves burocráticos para a tomada de decisões mais eficientes e a ausência de políticas nacionais de integração dos sistemas.

Na prática, o estudo revela a função condominial do CEASA, ou seja, um equipamento público, sem a eficiência e a flexibilidade exigida pelo mercado para controlar o curso da comercialização, logo, tornado privado pela alocação de empresas atacadistas e comerciantes. As centrais de abastecimento não oferecem serviços de comercialização, mas, sim, um depósito para a operação das empresas, dotadas de técnicas de capacidade de gestão de fluxos na rede de comercialização agrícola.

Apesar da realização, da circulação e da precificação ocorrerem no CEASA, majoritariamente, na década de 1980, o estudo da DECEN (1983) indica a apropriação do mercado atacadista por agentes presentes na comercialização, isto é, atravessadores e empresas atacadistas. Há, contudo, uma formalização das empresas localizadas no CEASA e uma concentração espacial das atividades de gestão da comercialização, dando importante destaque na realização do abastecimento de gêneros agrícolas.

Esse período também sinaliza a deficiência de uma articulação nacional do sistema de centrais de abastecimento e, em contrapartida, o crescimento das articulações das redes varejistas de supermercados. Ainda nesse sentido, a baixa articulação nacional, conforme indica Silva (1988), também comprometeu a formação de um sistema nacional de informações capaz de planejar e orientar as políticas públicas de abastecimento na década de 1990.

A década de 1980, portanto, foi basilar para o reposicionamento das centrais de abastecimento. Nesse período, o fim da articulação via SINAC orientou processos de privatização de algumas unidades do sistema CEASA, enquanto outras, como a unidade fluminense, foram repassadas aos governos estaduais por transferência de ações.

Segundo Cunha (2006), 
Já no final de 1986, com a crise fiscal do Estado brasileiro, levou-se a cabo o desmonte do Sistema Nacional de Abastecimento brasileiro, com a transferência do controle acionário das CEASAs para os estados e municípios. Como tal medida não foi precedida de qualquer regra de transição, institucional ou gerencial, rompeu-se a base central de todo o arcabouço metodológico que norteava a concepção sistêmica da intervenção governamental no setor (p. 39).

O autor relata o fim das trocas de informações técnicas, classificações e operações entre as unidades do CEASA no Brasil. De fato, tal medida retirou a capacidade de regulação na escala nacional do sistema público de abastecimento. Na mesma linha e pensando na unidade fluminense, o Governo do Rio de Janeiro não teve capacidade de promover as transformações técnicas necessárias para a modernização do sistema.

A década de 1990 revela a abertura comercial brasileira e um reposicionamento do papel estatal. Nesse contexto, a obsolescência nas CEASA-RJ é contemporânea à entrada das grandes redes transnacionais do varejo no Brasil. Não existe uma simples coincidência nessa situação, porquanto há uma intencionalidade dentro da lógica neoliberal de apropriação da capacidade regulatória do poder público. Em outras palavras, os supermercados se apropriam do funcionamento do CEASA, centralizando a comercialização e controlando os fluxos materiais e imateriais do sistema de abastecimento.

Para ampliar a argumentação, concorda-se com a leitura de Wegner e Belik (2012) sobre as articulações entre centrais de abastecimento e redes varejistas. Para os autores, não há uma concorrência entre um sistema moderno - os supermercados - e um ultrapassado - as centrais de abastecimento. Na verdade, há funções diferenciadas, ou seja, o CEASA-Rio ainda é fundamental para produtores familiares e varejistas de menor porte e, ao mesmo tempo, oferta parte da demanda dos supermercados.

A falta de investimento e de articulação entre as centrais de abastecimento revela a hegemonia das grandes redes transnacionais e a apropriação e o controle privado da função pública realizada pelo sistema de abastecimento. Sobre isso, Cunha (2006) afirma que 
Muitas vezes (os CEASAs) submetidos a interesses políticos locais, ou à influência dos agentes privados, que virtualmente se apropriaram da gestão, pressionando por tarifas e preços irreais, foi solapada a capacidade de sustentabilidade financeira de boa parte das empresas gestoras (p. $39)$.

A gestão dos fluxos por agentes privados fica ainda mais clara na perspectiva de Wegner e Belik (2012). Em suma,

\begin{abstract}
Apesar de nos anos 1990 e 2000, os volumes de frutas e hortaliças vendidas por empresas atacadistas serem robustos, o setor privado, leia-se as redes de supermercado, passou a coordenar a distribuição de hortifrúti especificamente para suas lojas e a desenvolver fornecedores exclusivos de hortifruti (p. 200).
\end{abstract}

Sem eliminar formas pretéritas, as grandes redes se apropriaram de estruturas de abastecimento e comercialização justamente no momento de reconfiguração das ações estatais no horizonte do neoliberalismo. $\mathrm{O}$ enfraquecimento técnico-logístico das centrais de abastecimento é analisado, neste texto, a partir de propostas intencionais de redução da regulação pública para ampliação das práticas mercantis. Na mesma linha, a capacidade transescalar das redes varejistas diante da ruptura das estratégias nacionais do antigo modelo de articulação - o SINAC - também fomentam a hegemonia do setor mercantil e a privatização da função pública ${ }^{3}$.

A gestão dos fluxos pela iniciativa privada gera, conforme afirma Cunha (2006), informações privilegiadas, como a formação dos preços e a disponibilidade dos produtos. Na perspectiva mercantil, tais mecanismos são transformados em diferenciais competitivos e formas de ampliação nas margens de lucro.

O acesso à informação e/ou o controle sobre esse processo determinam, no período atual, a capacidade e a intensidade de um agente influenciar no arranjo espacial da rede de comercialização no Estado do Rio de Janeiro. Da mesma maneira, os supermercados impactam o mercado consumidor controlando o tipo de produto mais vendido em determinados dias e reduzindo as unidades de manutenção de estoque.

\footnotetext{
${ }^{3}$ Não há juízo de valor entre os sistemas público e privado. O grande objetivo é apresentar as transformações inerentes ao processo de comercialização, estabelecendo, dessa forma, as atuais articulações e os parâmetros competitivos e técnicos em construção e os impactos desse processo nas relações de poder e sua territorialização.
} 
O Walmart, seguido por vários supermercados, implementou uma série de estudos e realizou várias medidas para reduzir o número de produtos ofertados (marcas distintas de um mesmo produto). As mudanças, na prática, retiram produtos com menor lucratividade, abrem espaço para produtos com marca própria e ajustam práticas de just in time.

Walmart Berg e Roberts (2012) afirmam:

\begin{abstract}
Na verdade, esperamos que o Walmart se beneficie desproporcionalmente do aumento de preços dos alimentos, dada a sua capacidade de atenuar certos aumentos de custos. Ele opera uma das cadeias de suprimentos mais eficientes no mundo, e agora começa a colher os benefícios da prospecção global de fornecedores, ou global sourcing (p. 73).
\end{abstract}

As práticas logísticas de otimização das compras superam os limites e as ações das centrais de abastecimento. A gestão e a atuação global das grandes redes varejistas transformam o sistema CEASA-RJ em um elo pontual da rede de comercialização, controlado e apropriado pelos supermercados e pela gestão privada. Seguindo Wegner e Belik (2012), o sistema CEASA-RJ atua como um prestador de serviços para as grandes redes pela sua capacidade de atuação atacadista, ou seja, de centralizar um representativo volume de produção de gêneros agrícolas, o que significa, também, uma forma de terceirização para os grandes varejistas.

Nessa linha, as técnicas logísticas são fundamentais para o CEASA-RJ ser um competidor eficiente e eficaz na rede de comercialização, ou seja, disputar mercado com operadores logísticos contratados pelos supermercados para garantir regularidade na distribuição de gêneros agrícolas à área metropolitana.

De fato, como indicam Wegner e Belik (2012), os supermercados determinam os padrões técnicos para embalagens e qualidade dos produtos e logísticos, como prazo de entrega e regularidade na distribuição. O resultado desse processo, concordando com Cunha (2006), é a apropriação privada dos excedentes gerados por estruturas públicas e o controle dos fluxos materiais e imateriais em circulação nas redes. 
As técnicas e as normas organizacionais são derivadas da importância dada, no período atual, à logística e à cadeia de suprimentos. Sem dúvidas, o aparato técnico-logístico representa um diferencial competitivo para as grandes varejistas transnacionais e para os operadores logísticos em atuação no Estado do Rio de Janeiro.

A excelência técnica cria condições mais precisas de gestão de fluxos materiais e imateriais nas redes de abastecimento e, com sistemas informacionais e estatísticos, permite aos supermercados exercer a centralidade no arranjo espacial estabelecido e em constante transformação, ligando as áreas de produção na Região Serrana ao consumo na Região Metropolitana. Logo, a logística, como sistema técnico-organizacional materializa a construção de práticas consensuais, com assimetria de poder, para produtores familiares, operadores logísticos e pequenos comerciantes.

\section{Mudanças, permanências e a o diferencial logístico: supermercados e central de abastecimento}

O termo logística para Silveira (2011) estabelece uma conexão para além do transporte, incorporando as interações ao longo da cadeia de suprimentos, isto é, da extração da matéria-prima até o consumidor e seu sentido inverso, com valores demandados pelo mercado consumidor.

Vitorino (2012) defende a gestão da cadeia de suprimentos como a nova fronteira competitiva no segmento empresarial. Além de produzir, é fundamental ser eficiente na circulação das mercadorias e controlar as informações (SANTOS, 2002). Assim, seguindo com Vitorino (2012), o principal papel do gestor na cadeia de suprimentos é equilibrar os fluxos de produção, de demanda e de custos, controlando a frequência e a intensidade da circulação de mercadorias.

Com o auxílio de Silveira (2011), verifica-se na circulação e na logística uma ferramenta fundamental no contexto da (re)produção do espaço, na redução de gastos das grandes empresas e na construção da hegemonia das grandes redes varejistas. Concordando com o autor, a análise da logística deve incorporar 
o transporte, as táticas e as situações de armazenagem da montante à jusante do sistema econômico (produtivo, comercial e de serviços), ou seja, do transporte e armazenamento das matérias-primas à entrega ao consumidor final (p. 23).

A leitura geográfica de Silveira (2011) interage com o referencial teórico e empresarial de Fleury et al (2000). O segundo analisa a logística como uma resposta aos anseios do mercado e à possibilidade tecnológica, gerando e gerenciando fluxos em todo o planeta. A implementação dos instrumentos técnicos permite a alocação do "produto certo, no local correto, no momento adequado e ao preço justo" (FLEURY et al., 2000, p. 28).

Entretanto, Silveira (2011) reforça a necessidade de integrar a logística e as técnicas no processo de (re)produção do espaço e do capital por meio de difusões heterogêneas de inovação, marginalizando e/ou sobrepondo modalidades de circulação menos eficientes ou produtivas. As interações espaciais são dotadas de intencionalidades, que elevam a complexidade da leitura do local, ou seja, a cadeia de suprimentos envolve uma leitura de ações horizontais e verticais carregadas de conflitos e assimetrias.

O texto de Vitorino (2012) apresenta vários exemplos de padrões considerados eficientes e competitivos. Os modelos de produção apresentados - "fabricação contra a previsão de demanda, fabricação sob encomenda e montagem conforme pedido" (p. 17) - indicam as possibilidades de gestão para uma mesma cadeia de suprimentos. Não há, portanto, uma cadeia com apenas um modelo de produção. Considerando a comercialização agrícola, a flexibilidade na articulação desses modelos deve ser ainda maior pela grande imprevisibilidade da produção ${ }^{4}$. Consequentemente, há um contínuo processo de transformação na territorialização dos nós - de produtores e consumidores - nas redes de abastecimento de gêneros agrícolas.

A montagem e a gestão da cadeia de suprimentos requerem a ampliação de possibilidades de fornecedores e a consequente redução de vulnerabilidades na oferta de produtos. Nesse sentido, as

\footnotetext{
${ }^{4}$ Mesmo com o arsenal tecnológico - sementes, irrigação, fertilização, defensivos e máquinas -, a produção agropecuária ainda carrega uma variabilidade muito maior do que a produção industrial, por exemplo, em virtude da maior dependência de fatores naturais e maior exposição às intempéries biológicas.
} 
redes hegemônicas organizam os fornecedores de gêneros agrícolas de operadores terceirizados para minimizar riscos de desabastecimento nas filiais.

O Esquema 1, a seguir, expõe um modelo atual de configuração da cadeia de suprimentos dentro da perspectiva de controle de vulnerabilidade e ampliação da eficiência. Há sempre um número maior de produtores, além de alguns em aguardo para integrar a rede a fim de suprir possíveis reduções de oferta. Os operadores logísticos são mais eficientes no reconhecimento de produtores, na organização da coleta dos produtos e na distribuição para os varejistas. Os varejistas não recorrem a um único operador logístico também para reduzir riscos de desabastecimento. A redundância ainda é uma realidade para a rede de abastecimento de gêneros agrícolas em virtude da maior imprevisibilidade da produção e, em menor grau, do consumo, graças aos mecanismos informacionais de controle da demanda.

\section{Comercialização Agrícola - Manutenção da Oferta de Produtos}

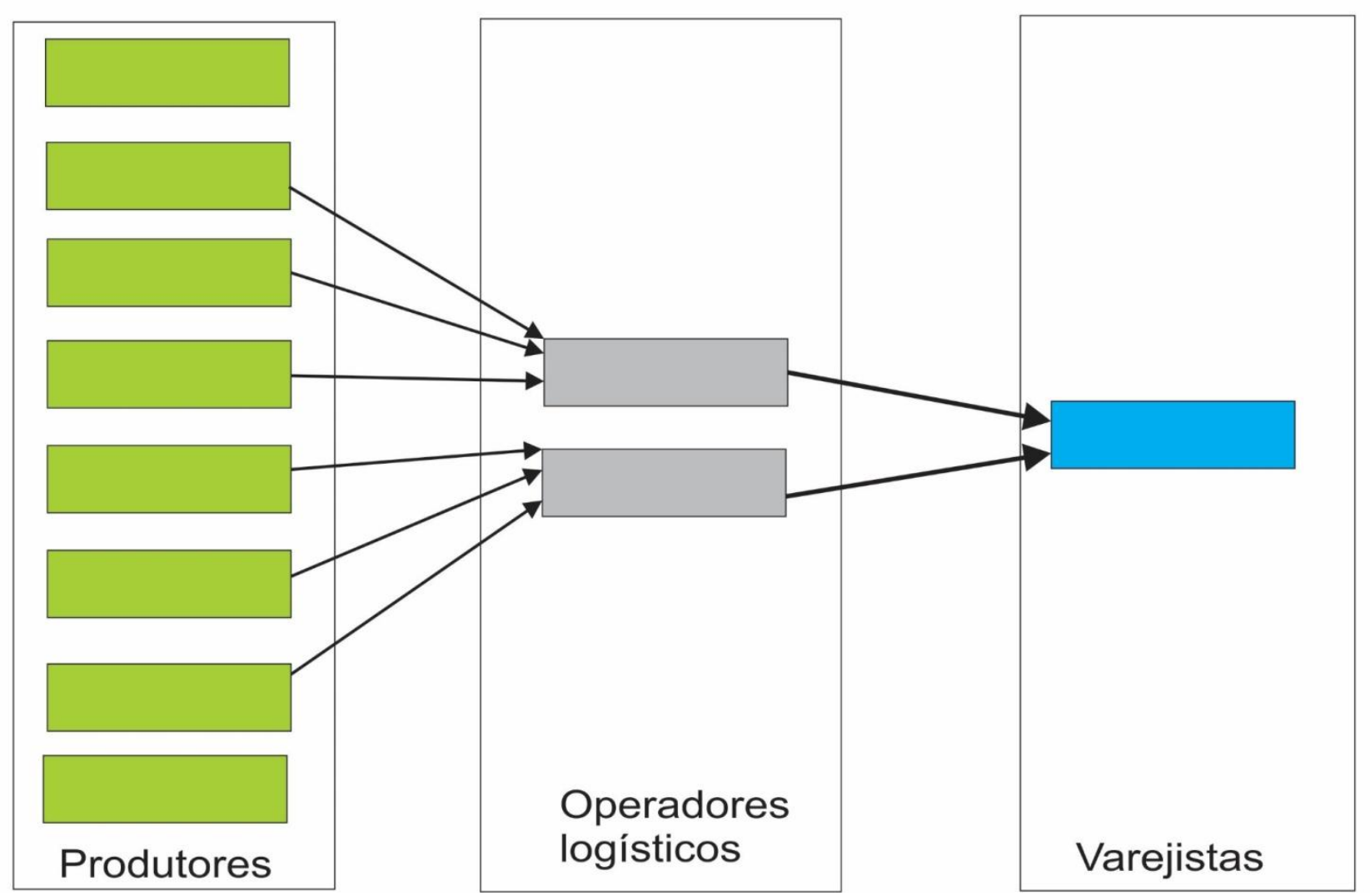

Esquema 1. Segmento da rede - redução de vulnerabilidades. Adaptação de Vitorino (2012) - Elaboração própria. 
A inserção de operadores logísticos também serve para o controle de estoques mínimos. A terceirização da coleta de produtos é fundamental para elevar a eficiência na distribuição dos produtos no tempo certo da demanda, principalmente para produtos perecíveis, como aqueles produzidos na área serrana fluminense, sobretudo no circuito Tere-Fri.

Para Vitorino (2012),

\footnotetext{
Na cadeia de suprimentos, a função do just in time é tornar o ciclo pedido-entrega-pagamento mais rápido. Mas como isso pode ser feito? A solução é simples: em vez de acumular pedidos enormes com diversos tipos de mercadorias, os fabricantes devem fazer pedidos menores, uma para cada tipo de material (p. 26).
}

O just in time é uma medida de produtividade na gestão da cadeia de suprimentos. Os operadores logísticos representam fixos eficientes na promoção da fluidez espacial e da gestão dos fluxos, capazes de operar os pedidos diários das grandes redes de acordo com cada filial de cada supermercado. Para Silveira (2011), "não basta só existirem fixos, mas é necessário também haver um ótimo de custos, velocidade, de conforto, de acessibilidade, de frequência, de seguridade, de descrição e de eficiência” (p. 46). Seguindo com o autor, a gestão da cadeia de suprimentos tem impacto na tecnificação dos espaços para dotá-los de fluidez, assim como estabelece os critérios para determinar processos considerados produtivos na circulação de produtos agrícolas.

$\mathrm{Na}$ rede varejista, o controle do estoque e a reposição das gôndolas são desafios logísticos principalmente quando se trata de produtos perecíveis como os gêneros agrícolas típicos da produção da Região Serrana Fluminense. Nesse contexto, Vitorino (2012) lembra das práticas de "estoque gerenciado pelo fornecedor (vendor-maneged inventory)" (p. 28), ou seja, de articulações entre software de supermercados e operadores logísticos, capazes de estabelecer, em tempo real, as demandas do varejista para o dia seguinte de acordo com as vendas do dia corrente.

O abastecimento por EDI - eletronic data interchange - automatiza os pedidos dos supermercados e gera respostas rápidas para a reposição do estoque de acordo com o fluxo de demandas. 0 estoque e a 
reposição nas filiais é de responsabilidade dos fornecedores - operadores logísticos - que, no caso da comercialização, credenciam produtores com maior capacidade de criar regularidade para as exigências geradas pelas grandes redes varejistas.

Como articulador de cadeias de suprimentos, o Walmart é referência global, em outras palavras, cria os padrões normativos. De fato, como evidenciam Berg e Roberts (2012), as interações entre o Walmart e seus fornecedores em todo o planeta une processos e sistemas de grandes empresas fornecedores, operadores e filiais - ao mesmo tempo em que, como lembra Silveira (2011), marginalizam os menores e ampliam a ação das grandes empresas transnacionais.

Segundo Berg e Roberts (2012), parte da liderança logística tem origem na primazia da tecnologia da informação e dos sistemas informatizados de transporte. A rede Walmart padroniza $90 \%$ do software nas filiais espalhadas pelo mundo, garantindo agilidade e flexibilidade nas decisões sobre fornecedores e consumidores. A utilização dos dados logísticos cria condições para a construção de relatórios sobre o comportamento dos consumidores ${ }^{5}$ e, portanto, a criação de estratégias para diferentes nichos de mercado, aliando produção, distribuição e consumo com os mecanismos da acumulação flexível.

Entretanto, analisando as operações logísticas, eficiência e flexibilidade não são grandezas diretamente proporcionais. Conforme o Esquema 2, um operador capaz de ofertar demandas de extrema irregularidades tem elevado custo, enquanto que as empresas focadas em redução de custos buscam demandas regulares. A melhor produtividade entre flexibilidade e eficiência (custo) tem origem nas mudanças técnicas e organizacionais, por exemplo, articulando sistemas de informática e processos de terceirização.

\footnotetext{
${ }^{5}$ Berg e Roberts (2012) apresentam o funcionamento do Retail Link, um sistema informacional capaz de informar o Walmart e seus fornecedores sobre o comportamento do mercado consumidor afim de agilizar respostas e prever demandas em cada filial da rede.
} 


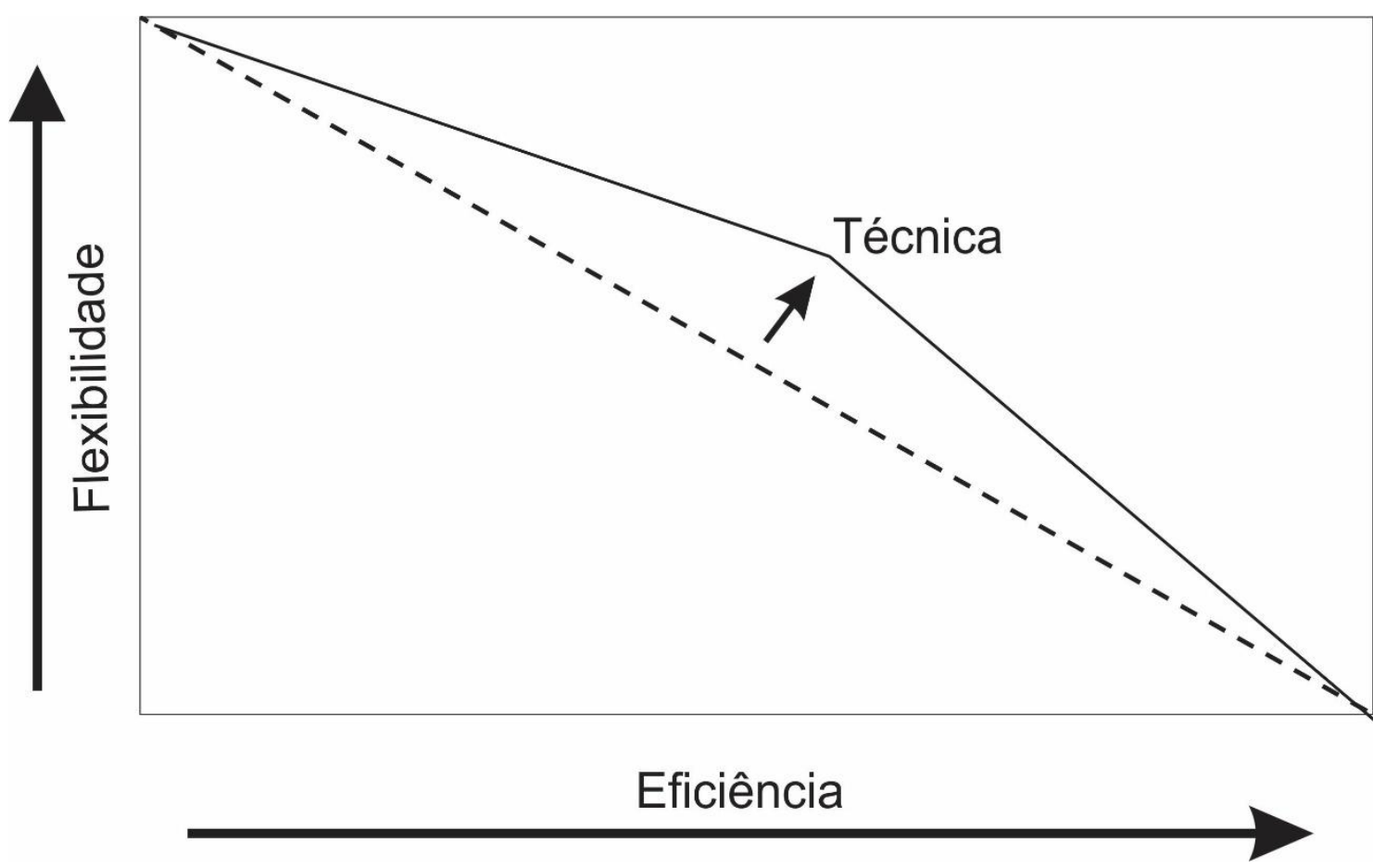

Esquema 2. A técnica como fundamento logístico. Fonte: Vitorino (2012, p. 55).

$\mathrm{Na}$ verdade, o gráfico não representa a realidade de uma empresa. As grandes redes varejistas são capazes de atuar sobre múltiplas formas de articulação entre eficiência e flexibilidade, atuando com menores preços e/ou buscando maior oferta de produtos. Nessa relação não linear, produtores familiares e intermediários constroem suas lógicas de resistência, integrando ou não os fluxos de suporte das grandes redes varejistas. No sentido contrário, os supermercados estabelecem dinâmicas e modelos de comercialização, integrando e marginalizando processos e fornecedores transversalmente costurados pelas relações capitalistas hegemônicas. Contudo, há múltiplas estratégias disponíveis de acordo com o produto e com o operador logístico; consequentemente, os supermercados configuram redes de eficiência e flexibilidade efetivando sua hegemonia do controle dos fluxos. Complementando, Silveira (2011) diz que

\footnotetext{
A logística é um desses atributos conceituais que reformulada é capaz de ampliar a eficiência das empresas multinacionais para que elas deem o próximo passo na conquista de mercados, ou seja, transformem-se em empresas globais. As condições estão dadas, isto é, o início do neoliberalismo, com desregulamentações, liberalizações etc. (p. 57).
}

A hegemonia das grandes redes varejistas passa pelo controle dos fluxos e pela padronização das normas de comercialização. Na prática, os supermercados ditam as previsões de demanda, porém 
encontram resistência ao procedimento nos produtores rurais ou nos próprios operadores logísticos. Retomando o Esquema 1, diferentemente das práticas de abastecimento de produtos industrializados, as redundâncias representam estratégias importantes para a realização de fluxos mais ancorados nas variantes demandas.

Apesar das estratégias de redundância para o controle da vulnerabilidade na oferta de produtos, a aceleração dos fluxos e as análises de resultados são procedimentos constantes para a logística dos supermercados. Como indica Fleury et al. (2000),

A mesma dinâmica que torna importante o desenvolvimento de processos baseados no tempo faz com que se torne fundamental a adoção de sistemas de mensuração de desempenho que sejam ágeis, abrangentes e consistentes. A logística opera num ambiente de grande diversidade, seja em termos de produtos, clientes, mercados, ou áreas geográficas. Portanto, para acompanhar as operações de forma adequada, e tomar decisões corretas e a tampo, é fundamental desenvolver sistemas de monitoramento de desempenho. As empresas de excelência logística possuem verdadeira obsessão com a mensuração de desempenho (p. 37).

As medidas de eficiência são transformadas em mecanismos de geração de eficiência, gerando padrões de sucesso copiados em modelos de benchmark (estudo e adaptação de um modelo operacional de uma empresa para outra) e estruturando referenciais de produtividade e competitividade. Esse contexto leva aos processos de desverticalização, ou seja, terceirização de atividades com baixo rendimento. Novamente com Fleury et al. (2000),

O que muitas empresas buscam nesse processo é o foco em sua competência central, repassando para prestadores de serviços especializados a maioria das operações produtivas. Uma das principais consequências desse movimento foi o crescimento da importância dos prestadores de serviços logísticos (p. 41).

Ao longo da estrada Teresópolis - Nova Friburgo e nas vias perpendiculares, encontram-se vários operadores logísticos, de diversos tamanhos, integrando várias redes de abastecimento. Há prestadores de serviços exclusivos para varejistas e operadores de grande porte atuando para vários supermercados e atravessadores formalizados em múltiplos canais de comercialização. De fato, a terceirização e a organização de operadores logísticos na Região Serrana representam um rebatimento das ações hegemônicas de logística - definição de normas de produtividade e eficiência - das grandes redes varejistas localizadas, sobretudo, na área metropolitana. 
A contratação de operadores logísticos reforça a necessidade e a centralidade dos elementos técnicos de informática, como as plataformas B2B (Business to Business ${ }^{6}$ ), os modelos compartilhados de gestão de estoques, os mecanismos de planejamento de rotas para os caminhões e a adequação de embalagens. Esse aparato técnico é extremamente dinâmico em virtude da escala global de competição entre as empresas, como lembra Barat (2011):

Com a globalização, os sistemas de produção flexível e a sofisticação das técnicas mercadológicas se redefiniram e os princípios da logística alteraram as prioridades e as estratégias. Surgiu uma preocupação maior com a racionalização de tempo e de custo, uma vez que a concorrência apenas em função da qualidade e de preço já não garantia a sustentação de vantagens competitivas (p. 219).

A logística está muito além do simples transporte de produtos, da gestão da cadeia de suprimentos e do planejamento de processos produtivos; ela representa a necessidade atual de reprodução ampliada e acelerada do capital, sob a égide do sistema financeiro exigente de ciclos cada vez mais curtos de produção dos lucros e da produção/apropriação de novos espaços/formas para a alocação dos excedentes. A logística está enquadrada nesse modelo buscando a aceleração dos fluxos e o arranjo reticular campos-cidades-redes para ampliar e viabilizar os investimentos e o retorno do capital. Há, portanto, uma intencionalidade na construção dos marcos regulatórios de produtividade e de eficiência. Consequentemente, os processos de inclusão e marginalização dos produtores familiares não advêm da opção simples de participar/não participar da rede articulada dos supermercados. Os processos são muito mais complexos e passam por transformações carregadas de sentidos históricos e interações entre o local e a entrada de racionalidades externas.

Como indica Vitorino (2012), na gestão da cadeia de suprimentos, "a ideia é trocar dados sobre os cronogramas de produção para fazer os membros da cadeia de suprimentos trabalhem no mesmo ritmo" (p. 87). Tal fato é inviável para vários produtores familiares, da mesma forma que o é para alguns operadores logísticos e para diversos atacadistas sediados no CEASA-Rio. Esse cenário impõe

\footnotetext{
${ }^{6}$ Integração entre empresas. Em geral, os sistemas de EDI - Eletronic Data Interchange - representam trocas instantâneas de informações para gerenciamento da cadeia de suprimentos.
} 
a configuração de múltiplos canais de abastecimento, com pontos de interseção e projeção de funções distintas sazonalmente para um mesmo agente.

Entre as exigências para contratação de empresas de logística, os supermercados, além da manutenção do fluxo contínuo de oferta, requisitam precisão da entrega, controle do estoque de cada filial e auxílio na reposição nas prateleiras de cada filial. A definição do $\mathrm{ROP}^{7}$ - Reorder Point - é determinada pelo varejista, enquanto a gestão é compartilhada com os operadores logísticos.

Reiterando o aspecto não linear dessas práticas, a resposta local de processos globalizantes promove idiossincrasias derivadas de mecanismos horizontais e verticais simultâneos com intensidades distintas ao longo do tempo, potencializando a diversidade de canais de comercialização. Nesse sentido, Berg e Roberts (2012) lembram os descaminhos da expansão global da maior rede varejista de supermercados do planeta. Segundo eles,

\footnotetext{
No espaço de 10 anos, o Walmart se envolveu em uma onda rápida de joint ventures, aquisições e entradas orgânicas ${ }^{8}$ em uma mistura de mercados maduros e emergentes. A distinção entre mercados maduros e emergentes é importante: os maiores sucessos do Walmart vieram dos mercados emergentes, onde a logística e filosofia CBTD $^{9}$ sofisticadas do varejista lhe permitiram ganhar uma posição superior, minar as redes locais e ter uma ótima receptividade por parte dos clientes menos afluentes. Por outro lado, os fracassos mais humilhantes do Walmart ocorreram nos modernos setores de varejo maduros, onde o Walmart Internacional tinha uma estratégia para estabelecer uma hegemonia local (p. 225).
}

As diferenças na atuação e no resultado ratificam o caráter múltiplo da comercialização agrícola, as possibilidades e as territorialidades presentes em redes sobrepostas e nos variados canais acionados pelo CEASA-Rio. As técnicas estabelecem padrões sem apagar a história e a geografia do local, assim como não podem inviabilizar resistências. A logística empresarial e a gestão da cadeia de suprimentos são hegemônicos e não homogeneizantes.

\footnotetext{
${ }^{7}$ Ponto de reposição.

${ }^{8}$ Entrada orgânica representa a montagem de uma rede própria do Walmart, isto é, sem compra de redes locais e transformação de procedimentos. Há um processo partindo do zero para a formação de uma cadeia de suprimentos para o Walmart.

${ }^{9}$ Representa a política de compras do Walmart - Custo Baixo Todo Dia.
} 
As múltiplas dinâmicas, os canais e as redes de comercialização compõem um cenário social e espacial complexo e dinâmico. Os padrões logístico-hegemônicos, assim como a atuação dos operadores terceirizados, sofrem constantes alterações e ressignificações a longo prazo. Há antigos e novos agentes em convívio e encontram-se trocas no papel desempenhado pelos agentes.

\section{As formas da rede de comercialização no Estado do Rio de Janeiro no período atual}

Carneiro e Rocha (2009), ao pesquisarem a produção familiar na Região Serrana Fluminense, são enfáticas ao apontar a comercialização como o principal entrave para os agricultores daquela região. Seguindo com as autoras, compreender os mecanismos de comercialização passa, também, pela análise do acesso à terra articulado com o sistema de intermediação.

Nesse sentido, a propriedade da terra influencia, em geral, nos mecanismos usados pelos produtores para escoar a produção ao mercado metropolitano. De acordo com Carneiro e Rocha (2009), o sistema de parceria é dominante na Região Serrana e inclui as áreas de produção no circuito Tere-Fri. Tal modelo explica a dependência de trabalhadores parceiros, sobretudo meeiros, aos atravessadores que, muitas vezes, são os proprietários. Além da relação propriedade da terra e intermediação, os atravessadores cumprem o papel de legalização da produção. Nas palavras de Carneiro e Rocha (2009),

\footnotetext{
O fato da maioria (dos produtores) não possuir registro aumenta a dependência aos comerciantes, que fornecem a nota fiscal como se tivessem sido eles próprios os produtores. Soma-se aos prejuízos causados aos pequenos agricultores por essa prática bastante difundida, a evasão do ICMS do município produtor para o de Teresópolis, de onde provém grande parte desses atravessadores, contribuindo assim para a fraqueza orçamentária das secretarias de agricultura dos demais municípios (p. 273).
}

A citação é fundamental para, primeiro, apresentar o município de Teresópolis como a localização da maioria dos operadores logísticos e, segundo, retirar a condição de produtor dessas empresas. De fato, há empresas com produção agrícola, todavia sua produção não é suficiente para equalizar os fluxos demandados pelo consumo na área metropolitana e, portanto, os operadores logísticos funcionam como 
atravessadores para diversos produtores rurais, pois trabalham buscando a produção diretamente com o produtor (Foto 1$)$.

A necessidade da nota fiscal para os produtores rurais é um impedimento para a realização da comercialização de forma direta, isto é, com os consumidores localizados na área urbana. Entende-se, pois, a exigência fiscal como uma forma de ampliar a participação das empresas de distribuição de gêneros agrícolas da região, que, na verdade, refletem a legalização-formalização de antigos atravessadores (hoje atuando como operadores logísiticos).

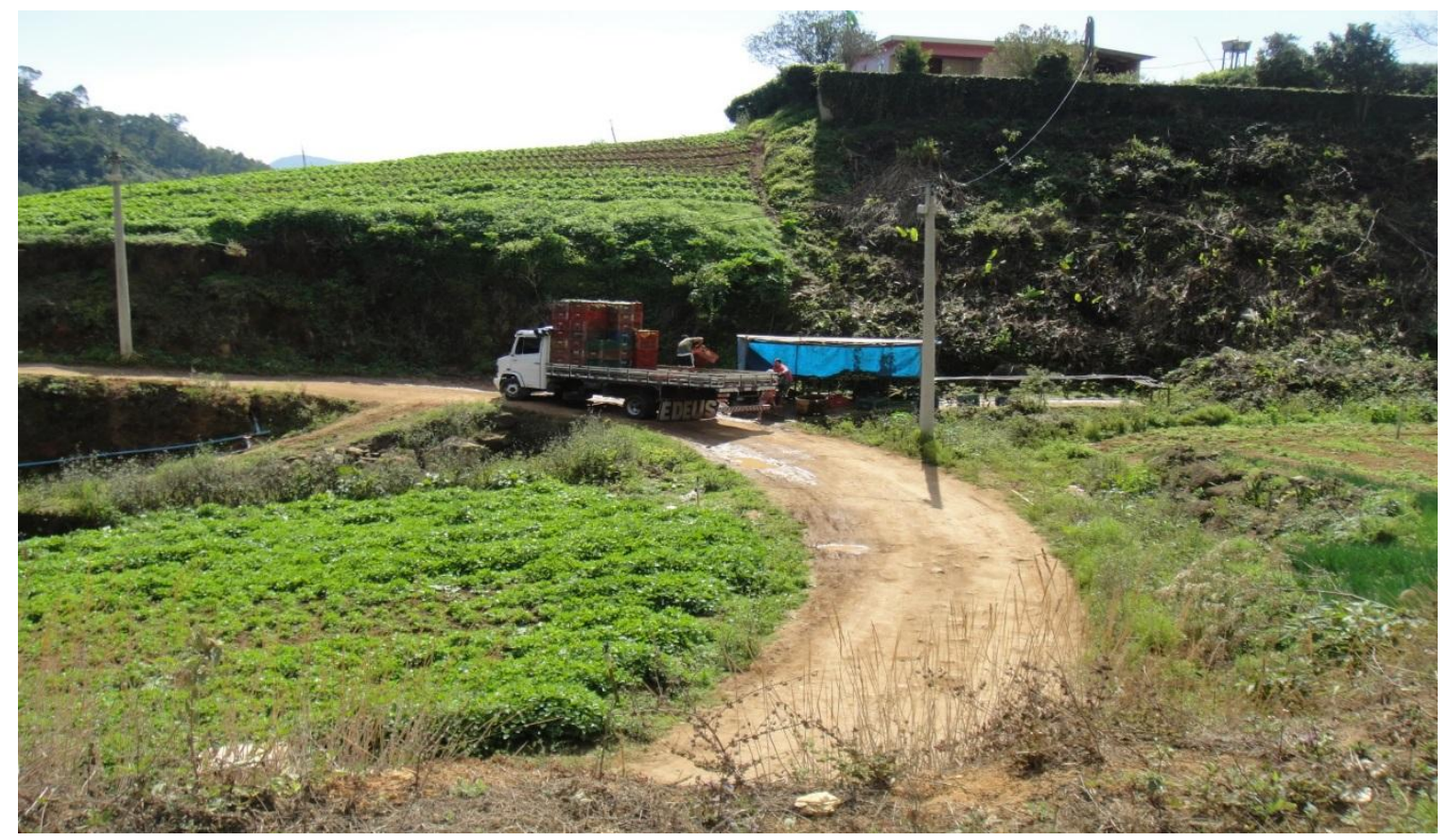

Foto 1. Carregamento do caminhão de empresa de intermediação. Fonte: Trabalho de campo: agosto de 2014.

Dentre os principais operadores logísticos localizados em Teresópolis, o grupo JFC - José Ferreira Campanha - é responsável pela distribuição de produtos agrícolas, em geral hortícolas, para várias redes varejistas na área metropolitana. Somente para o município do Rio de Janeiro, diariamente, são 40 caminhões articulando a área de produção e os supermercados.

A empresa obtém de 20 a 30\% dos produtos agrícolas de áreas próprias de produção, enquanto que 0 restante tem origem em diversos produtores localizados na área serrana e buscam padronização e 
produtividade para os produtos. Portanto, o grupo JFC assessora seus fornecedores com serviços de extensão rural. Os produtos, como indica o Esquema 2, são transportados até o galpão da empresa e, em seguida, selecionados, separados por cliente e destino, embalados e carregados nos caminhões.

\section{Organização logística - Grupo JFC}

\section{Legenda:}
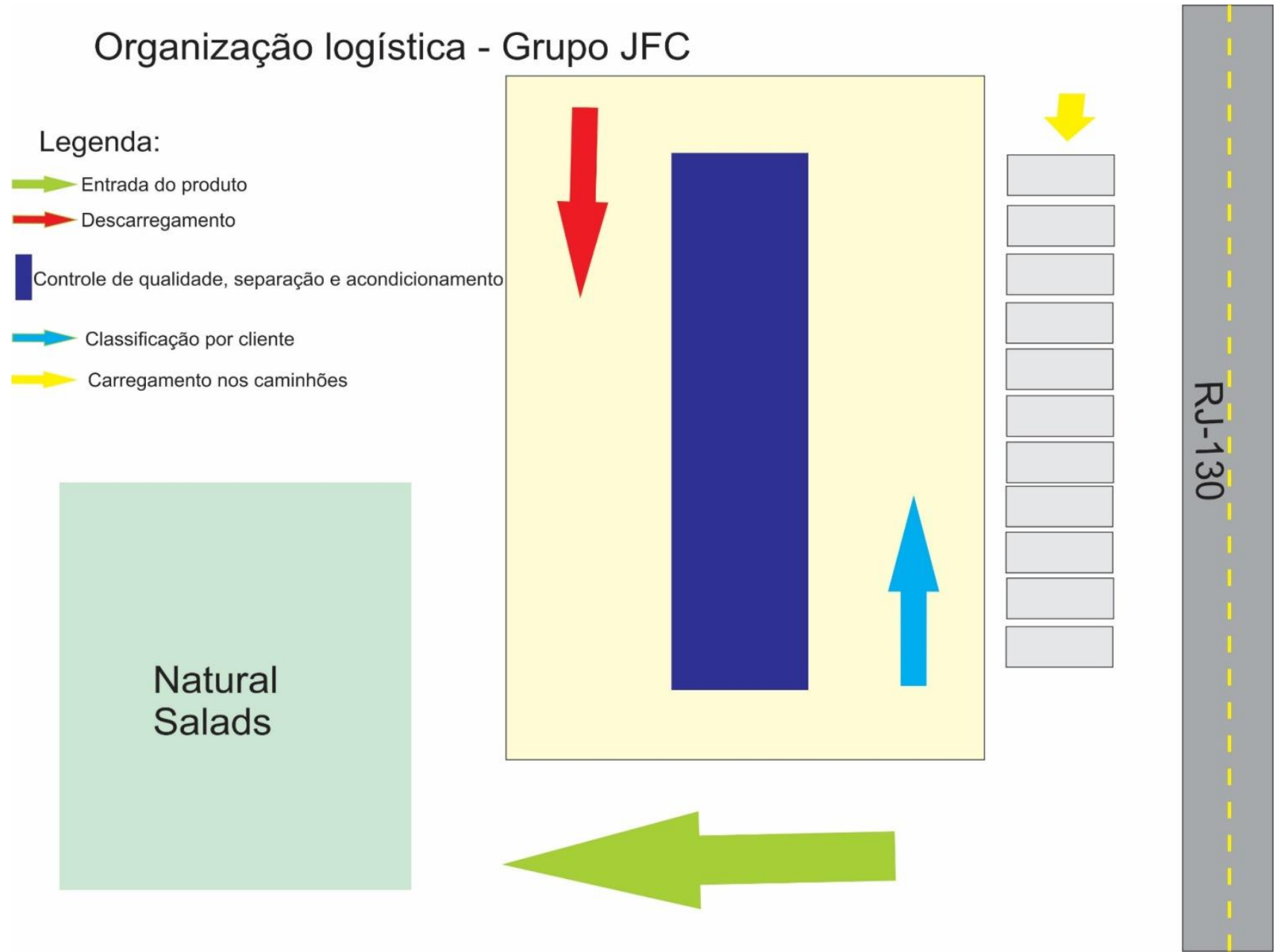

Esquema 2. Macro-organização do grupo JFC. Fonte: Trabalho de campo - Janeiro - 2013 - Elaborado pelo autor.

O principal centro logístico do grupo JFC fica em Teresópolis, na margem da estrada RJ-130 ${ }^{10}$, próximo aos produtores do circuito Tere-Fri. A organização logística do grupo reflete a transformação dos antigos atravessadores em operadores logísticos dotados de grande capacidade de gerar oferta contínua de produtos para as redes varejistas.

\footnotetext{
${ }^{10}$ Estrada Teresópolis - Nova Friburgo.
} 
Os caminhões do operador compram a produção de diversos agricultores, sem exclusividade. Na prática, há produtores integrados ao circuito de compras do grupo, com capacidade de gerar oferta contínua e, em casos de aumento da demanda, o grupo busca novos fornecedores para garantir o produto para a rede varejista. Nesse sentido, é impossível tratar os produtores familiares como um bloco homogêneo, isto é, enquanto há oferta dos maiores fornecedores, os menores buscam outros canais de comercialização. Entretanto, na baixa oferta, vários pequenos produtores são inseridos no circuito da empresa e outros, como forma de resistência, se recusam a vender a produção para o grupo.

Conforme relatou o trabalhador rural $\mathrm{R}^{11}$, o grupo atua para os produtores desconectados do circuito como um "pirangueiro". Para os trabalhadores rurais, essa palavra representa o intermediário que "só vem na boa"12. Na verdade, o grupo atua de acordo com a demanda varejista, desligando e ligando os produtores de acordo com a necessidade do varejista. No mesmo sentido, o produtor rural, no momento de baixa oferta e elevada demanda, escolhe o canal de comercialização, participando de múltiplos canais e de processos de resistência, cooptação e consentimento. A relação hierárquica entre produtores e os operadores logísticos tem uma organização fluida, isto é, de acordo com a demanda gerada pelo consumidor/cliente da empresa transportadora.

Retornando ao Esquema 2, o produto agrícola entra na área de descarregamento da central de distribuição (Foto 2) para, posteriormente, passar pelo processo de controle de qualidade, separação e acomodação em embalagens. De fato, além da fluidez e da capacidade de manter uma oferta constante, essa etapa representa mais um momento de agregação de valor ao produto agrícola e de demonstração, por parte das redes varejistas, da capacidade de construir normas para embalagem, acondicionamento e transporte do produto.

${ }^{11}$ Trabalho de campo no dia 2 de agosto de 2014 . 


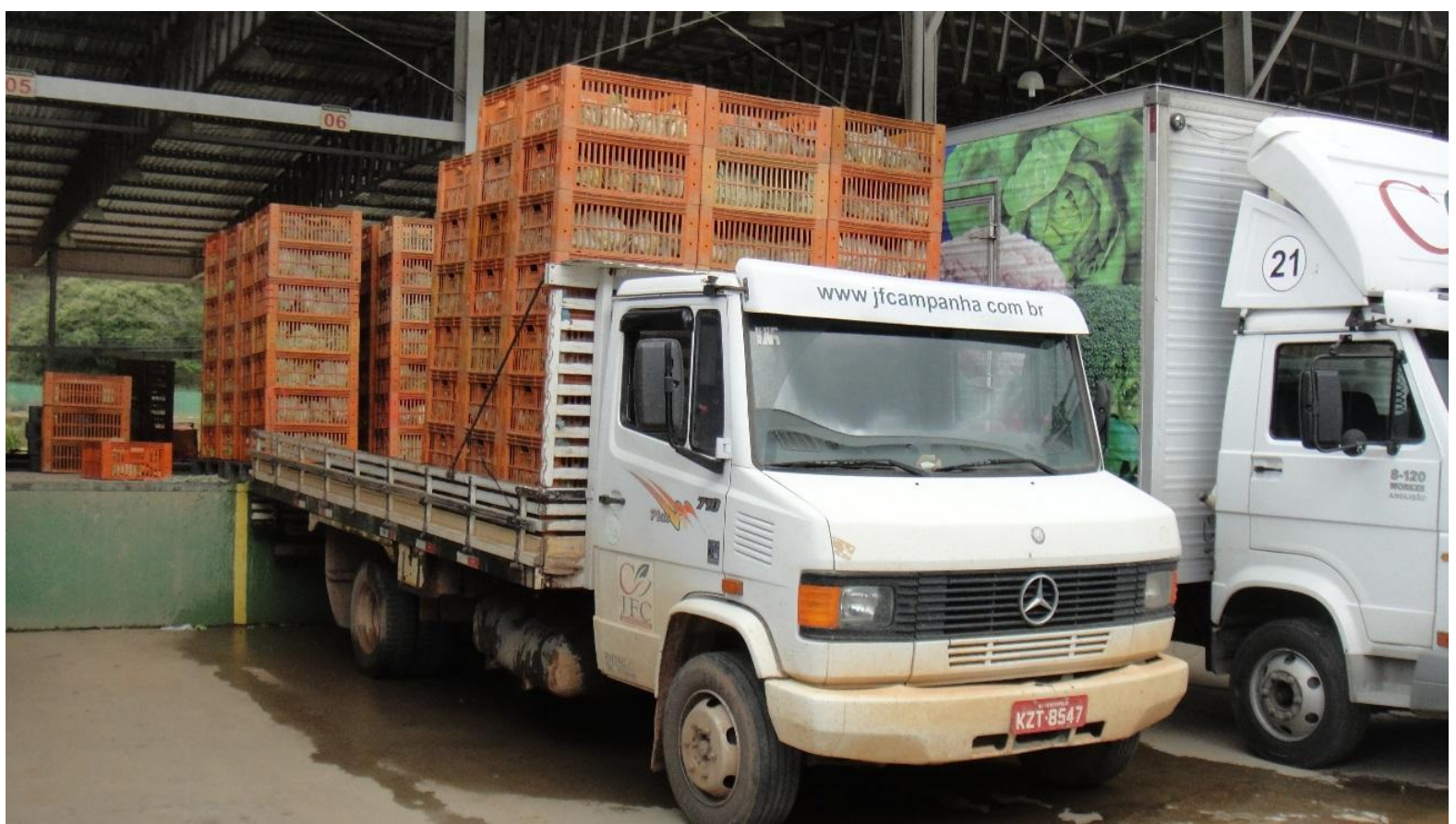

Foto 2. Descarregamento na plataforma de distribuição. Fonte: Trabalho de campo - Janeiro de 2013.

Em seguida, os produtos são discriminados por supermercado e pelas filiais de demandantes nas diferentes redes varejistas. Nesse momento, os sistemas computacionais são aceleradores da comercialização, pois o check-out ${ }^{13}$ dos supermercados indica, em tempo real, as vendas e a redução do estoque dos produtos. De posse dos números de cada filial, a rede remete ao operador logístico a demanda por produto para cada filial de forma automatizada. Os produtos são organizados dentro dos caminhões refrigerados (Foto 3) de acordo com os sistemas de cálculo de cubagem (volume de cada caminhão) e o destino de cada caminhão é orientado e controlado por programas de localização via satélite.

A entrega é feita nas diferentes filiais com acordos de reposição por parte do fornecedor; em outras palavras, um funcionário do grupo JFC é responsável pela alocação do produto na gôndola do supermercado. Além da redução de custo com a contratação de mão de obra, o supermercado repassa 0 gasto com a manutenção e o gerenciamento do estoque daqueles produtos para o fornecedor. Tal prática indica uma realocação do estoque ao longo da cadeia de suprimentos, bastante diferente de qualquer ideia de eliminação do estoque.

\footnotetext{
${ }^{13}$ Caixa registradora.
} 


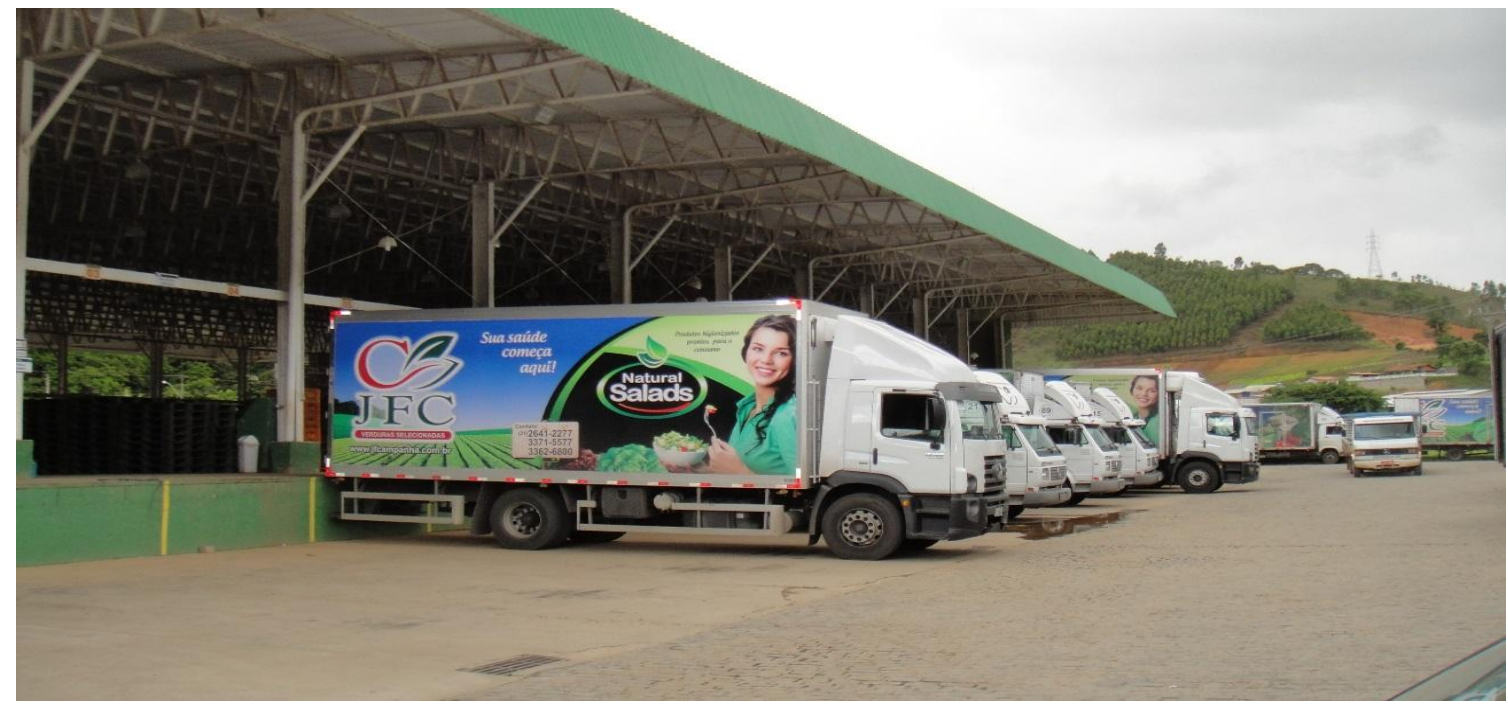

Foto 2. Carregamento dos caminhões. Fonte: Trabalho de campo - Janeiro de 2013

As técnicas empregadas objetivam a prática de just in time, fundamental para produtos perecíveis e para a redução de custos logísticos, assim como representam um conjunto de transformações na configuração da rede de comercialização. Na prática, os operadores logísticos são basilares para a aceleração dos fluxos e a materialização da lógica hegemônica-normativa das grandes redes varejistas. Ao mesmo tempo, de fato, essas empresas representam uma concentração de capital - em nome da produtividade e eficiência - dos inúmeros intermediários atuantes na região como já indicara Becker (1966), apesar dos novas estratégias, técnicas e tempos.

Além da agregação de valor pela logística, o grupo JFC tem uma plataforma de distribuição exclusiva para uma linha de produtos higienizados e embalados após um controle de qualidade mais rígido. A linha natural salads, com maior valor agregado e destinada a um nicho de mercado diferente do outro segmento, indica uma transformação nas articulações na comercialização agrícola no Estado do Rio de Janeiro, pois o operador logístico é um prestador de serviços de transporte e de transformação do produto.

\section{CONSIDERAÇÕES FINAIS}


A localização do grupo JFC e da empresa Tuti-Fruti revela um dado da configuração espacial da comercialização agrícola na área serrana. Ambos localizados na margem da rodovia RJ-130 articulam da estrada seus fornecedores e sua mercadoria para a área metropolitana.

Além das duas plataformas empresariais, a rodovia também abriga a unidade do CEASA-RJ regional, a unidade serrana de Nova Friburgo. Na prática, a centralidade exercida pelos entrepostos privados representa a apropriação da função pública de gerenciar os fluxos comerciais daquela área. 0 mercado público não carrega os instrumentos logísticos considerados eficientes e o desenvolvimento de sistemas de transportes e telecomunicações mais eficientes ele permite o transporte direto para um entreposto mais próximo do consumidor final.

A redução no número de intermediários significa, para o produtor rural, a obtenção de uma parte maior da receita oriunda do trabalho no campo. Contudo, de fato, o transporte, mesmo quando direcionado para a unidade Grande Rio do sistema CEASA-RJ, é realizado por atravessadores que, em geral, são proprietários e estabelecem com os trabalhadores sistemas de parceria (meação $)^{14}$.

Com a localização do eixo rodoviário da RJ-130 os operadores centralizam os fluxos das estradas vicinais e, em maior grau para os operadores privados, remetem esses produtos para a área metropolitana do Estado do Rio de Janeiro, diretamente para as filiais dos grandes varejistas.

Há, consequentemente, uma sobreposição de canais de comercialização interativos, capazes de reconfigurar constantemente o arranjo da rede de comercialização e a atuação dos produtores familiares. É possível identificar, também, as diferenças técnicas entre os distintos canais em operação e, desse modo, as permanências e as transformações nas normas de comercialização.

Além das grandes empresas de comercialização, há inúmeras empresas menores realizando o transporte e a comercialização para a área metropolitana. Como já indicado por Carneiro e Rocha

\footnotetext{
${ }^{14}$ Esse parágrafo foi baseado nas informações coletadas nos trabalhos de campo realizados nos municípios de Teresópolis e
} Nova Friburgo. 
(2009), a exigência de nota fiscal elevou o número de pedidos e a concretização de várias empresas de comércio atacadista no município de Teresópolis.

De fato, os múltiplos canais e formas de comercialização são, em alguma medida e nessa área de estudo, relacionados à existência dessa diversidade de empresas, com capacidade de transporte e práticas logísticas diferenciadas. A propósito, diante da necessidade de reprodução social, os agricultores familiares se inserem ou são inseridos nos múltiplos canais, materializando as formas de resistência quando não vendem para aqueles considerados como "pirangueiros" e consentem com o processo quando estabelecem relações de oferta contínua de produtos para uma empresa. A transformação constante dessas práticas revela a metamorfose da rede de comercialização e, consequentemente, das articulações entre cidade e campo.

Ainda nesse contexto, a forma de escoamento da produção agrícola no eixo da RJ-130 também deve ser relacionada ao acesso à propriedade da terra. Com base em relatos de campo, a maioria dos trabalhadores em regime de meação relatam a "parceria" com o proprietário da terra responsável por transportar e vender a produção na unidade Grande Rio do sistema CEASA-RJ.

Outro aspecto indicado pelos produtores é a exigência de qualidade e produtividade por parte dos canais mais dinâmicos, ou seja, aqueles diretamente conectados aos grandes estabelecimentos varejistas na área metropolitana. Há, nesse sentido, uma referência normativa dos supermercados capaz de diferenciar os produtores e os canais de comercialização. Logo, entendem-se as forças hegemônicas de caráter global como produtoras de diferenciação, assim como são dialeticamente envolvidas com processos relacionados a temporalidades pretéritas.

Toda a dinâmica de comercialização e o acesso à terra também são relacionados aos escassos recursos de assistência técnica investidos na produção familiar no circuito Tere-Fri. Durante as entrevistas, os produtores rurais enfatizaram as dificuldades dos técnicos públicos, sobretudo da EMATER-RJ, e dos sistemas de financiamento da pequena produção de hortaliças, legumes e verduras, principalmente para trabalhadores em sistema de parceria. 
Assim, verificam-se práticas neoliberais de redução da regulação pública e a possibilidade de apropriação mercantil de nichos da função pública de regulação e logística na comercialização de gêneros agrícolas. A presença de técnicos agrícolas do Grupo JFC com os produtores responsáveis pela oferta de produtos para a empresa materializa mais uma ramificação da regulação privada do abastecimento de gêneros agrícolas.

O resultado de todo esse processo é a articulação de múltiplas redes interagindo em múltiplas escalas. A definição de uma única função para um produtor familiar e até para um operador logístico é uma tarefa independente da variável tempo.

\section{REFERÊNCIAS}

BARAT, Josef. Infraestruturas de logística e transporte: análise e perspectivas. In. SILVEIRA, Márcio Rogério. (org.). Circulação, transportes e logísticas diferentes perspectivas. São Paulo: Outras Expressões, 2011. p. 217-246.

BECKER, Bertha K. 0 mercado carioca e seu sistema de abastecimento. Rev. Bras. Geogr., 28(2). Rio de Janeiro: IBGE, 1966.

BERG, Natalie; ROBERTS, Roberts. Walmart: A estratégia vencedora do gigante do varejo mundial. Rio de Janeiro: Elsevier, 2012.

BICALHO, Ana Maria de Souza Mello. Agricultura e Ambiente no Município do Riode Janeiro. In: ABREU, Maurício de Almeida (Org.). Sociedade e Natureza no Rio de Janeiro. Cap. 9, Rio de Janeiro: Prefeitura da Cidade do Rio de Janeiro, 1992. p. 285-316.

CARNEIRO, M. J. Limites e possibilidades da construção de 'territórios de desenvolvimento. In: CAZELLA; BONNAL; MALUF. (Org.). Agricultura Familiar: multifuncionalidade e desenvolvimento territorial no Brasil. 1 ed. Rio de Janeiro: Mauad X, 2009. p. 271-290.

CEASA-RJ. Informativo de mercado. Abril de 2014.

CUNHA, A. R. A. A. Dimensões estratégicas e dilemas das centrais de abastecimento. Revista de Política Agrícola, Brasília, n. 4, 2006.

DECEN. Condensação das conclusões levantadas no encontro de dirigentes de CEASAS. Brasília: MAPA, 1983.

FleURY, P. F.; FigUeiredo, K. F.; WANKE, P.. Logística Empresarial - A Perspectiva Brasileira. Coleção COPPEAD de Administração. São Paulo: Atlas, 2000.

GALVÃO, Maria. Percursos geográficos. Rio de Janeiro: Lamparina/PPGG-UFRJ, 2009.

GAWRYSZEWSKI, Alberto. Panela Vazia: o cotidiano carioca e o fornecimento de gêneros alimentícios - 1945/50. Rio de Janeiro: Secretaria Municipal das culturas, 2002, p. 43. 
GUIMARÃES, Alberto Passos. Formação da pequena propriedade: intrusos e posseiros. Camponeses brasileiros: leituras e interpretações clássicas, v.1. São Paulo: UNESP; Brasília. Núcleo de Estudos Agrários e Desenvolvimento Rural, 2009.

LAVINAS, Lena; NABUCO, Maria Regina (Coord.) Crise, Abastecimento e uso do Solo - Relatório Parcial IV. Rio de Janeiro. Dezembro de 1992.

LINHARES, Maria Yedda Leite. História do abastecimento uma problemática em questão (1530-1918). Brasília: BINAGRI, 1979.

MOREIRA, Ruy Sociedade e espaço geográfico no Brasil. 1. ed., v.1. São Paulo: Contexto, 2011.

PRADO JR, Caio. A Questão Agrária Brasileira. 5ª ed. São Paulo: Brasiliense, 2000.

SANTOS, Milton. A natureza do Espaço: técnica e tempo, razão e emoção. São Paulo: Edusp. 2002.

SILVA, Ivan Moreira. Plano de Diagnóstico e Avaliação das Ceasas. Brasília: MAPA, 1988.

SILVEIRA, M. R. Geografia da Circulação, Transportes e Logística: Construção Epistemológica e Perspectivas. In: SILVEIRA, Márcio Rogério (Org.). Circulação, Transportes e Logística: diferentes perspectivas. 1 ed. São Paulo: Outras Expressões, 2011.p. 21-67.

VILELA, Mário Ramos. 0 abastecimento e o setor público agrícola. Brasília: MAPA, 1978.

VITORINO. Carlos Márcio. Logística: bibliografia universitária Pearson. São Paulo: Pearson, 2012.

WEGNER, R. C.; BELIK, Walter. Distribuição de hortifruti no Brasil: papel das Centrais de Abastecimento e dos supermercados. Cuadernos de Desarrollo Rural, v. 69, p. 195-220, 2012. 